\title{
PENDAMPINGAN PENYUSUNAN BAHAN AJAR DENGAN TEMA “PENERAPAN PEMBELAJARAN REALISTIC MATHEMATIC EDUCATION MENGGUNAKAN BARANG BEKAS" PADA GURU SEKOLAH DASAR BANTARAN SUNGAI CITARUM (Program Pengabdian Di desa Dayeuhkolot Kecamatan Dayeuhkolot Kabupaten Dayeuhkolot)
}

\author{
Sukma Murni ${ }^{1}$, Sylvia Rabbani ${ }^{2}$, Heris Hendriaana ${ }^{3}$ \\ 1,2,3 IKIP Siliwangi \\ sukma murni@ikipsiliwangi.ac.id¹ㄴ, sylviarabbani@ikipsiliwangi.ac.id²
}

\begin{abstract}
ABSTRAK
Secara umum, tujuan jangka panjang program pengabdian ini adalah mengembangkan suatu proses pengabdian yang inovatif melalui pendampingan bagi guru-guru SD dalam upaya meningkatkan kualitas pembelajaran dan kualitas guru SD di Dayeuh Kolot melalui hasil-hasil penelitian pendahuluan yang telah dilakukan. Secara khusus, target khusus yang ingin dicapai sebagai berikut: (1). Meningkatkan pemahaman dan penyusunan bahan ajar dengan tema "Penerapan Pembelajaran Realistic Mathematics Education Menggunakan Barang Bekas" pada guru SD Bantaran Citarum; (2). Meningkatkan minat pemahaman dan penyusunan bahan ajar dengan tema "Penerapan Pembelajaran Realistic Mathematics Education Menggunakan Barang Bekas" pada guru SD Bantaran Citarum. Metode pelaksanaan dalam pencapaian tujuan tersebut sebagai berikut: (a). perizinan terhadap Dinas setempat terkait pengabdian terhadap guru-guru SD; (b). Memberikan gambaran umum mengenai kegiatan pengabdian yang akan dilakukan; (c). Melakukan refleksi dan diskusi mengenai berbagai kegiatan pengabdian yang akan dilakukan; (d). Melakukan kolaborasi dengan ahli dalam menyusun bahan ajar dengan tema "Penerapan Pembelajaran Realistic Mathematics Education Menggunakan Barang Bekas" pada guru SD Bantaran Citarum, (e). Pelaksanaan kegiatan pendampingan ; (f). Evaluasi kegiatan pendampingan, (f) Penarikan kesimpulan pelaksanaan pendampingan, dan (g) Publikasi luaran pengabdian.
\end{abstract}

Kata Kunci: Pendampingan, Bahan Ajar, Realistic Mathematics Education.

\begin{abstract}
In general, the long-term goal of this service program is to develop an innovative service process through mentoring for elementary school teachers in an effort to improve the quality of learning and the quality of elementary school teachers in Dayeuh Kolot through the results of preliminary research that has been conducted. Specifically, the specific targets to be achieved are as follows: (1). Improving the understanding and preparation of teaching materials with the theme "Application of Realistic Mathematics Education Learning Using Used Goods" on Bantaran Citarum elementary school teachers; (2). Increasing interest in understanding and compiling teaching materials with the theme "Application of Realistic Mathematics Education Using Used Goods" to Bantaran Citarum elementary school teachers. The method of implementation in achieving these objectives is as follows: (a). licensing of local Dinas related to dedication to elementary school teachers; (b). Provide a general description of the service activities that will be carried out; (c). Conduct reflections and discussions regarding various service activities that will be carried out; (d). Collaborating with experts in preparing teaching materials with the theme "Application of Realistic Mathematics Education Using Used Goods" to Bantaran Citarum elementary school teachers, (e). Implementation of assistance activities; (f). Evaluation of assistance activities, (f) Drawing conclusions from the implementation of assistance, and (g) Publication of service outcomes.
\end{abstract}

Keywords: mentoring, Realistic Mathematics Education, Material teaching 


\section{A. PENDAhUluAN}

\section{Latar Belakang Pengabdian}

Berdasarkan hasil penelitian yang telah dilakukan oleh Murni (2017) tentang peningkatan suatu kemampuan matematik melalui pembelajaran dengan pendekatan Realistic Mathematics Education (RME). Selain itu hasil pengabdian yang telah dilaksankan oleh (Rahayu dan Firmansyah, 2018) tentang metode pendampingan dalam meningkatkan pemahaman dalam pembelajaran inovatif di SD. Dari hasil penelitian dan pengabdian tersebut dapat disimpulkan bahwa RME atau aplikasi matematika dalam kehidupan sehari-hari dapat diterapkan untuk pemanfaatan barang bekas dan pendampingan dapat memberikan dampak pada berbagai keterampilan dan kemampuan. Barang bekas atau sampah merupakan bahan padat buangan dari kegiatan rumah tangga, pasar, perkotaan, hotel, penginapan dan lainnya. Sampah merupakan hasil sampingan dari aktivitas manusia yang sudah terpakai. Sampah biasanya dibuang ketempat yang jauh dari pemukiman penduduk. Jika sampah dibuang disekitar pemukiman penduduk maka resiko bagi kesehatan sangat besar. Sampah yang dibiarkan menggunung dan tidak diproses atau didaur ulang bisa menjadi sumber penyakit bagi manusia (Sucipto, 2012:01). Akan tetapi dari hasil kajian penelitian dan pengabdian tesebut masih terdapat kesenjangan yaitu belum adanya pengabdian menggunkaan pendampingan dalam penyusunan bahan ajar dengan tema dengan tema "Penerapan Pembelajaran Realistic Mathematics Education Menggunakan Barang Bekas" pada guru SD Bantaran Citarum. Oleh karena itu, pada pengabdian ini akan melaksanakan pendampingan terhadap guru-guru SD di Dayeuh Kolot dalam meningkatkan pemahaman menyusun bahan ajar pada guru-guru SD.

\section{Hal-Hal Yang Melandasi Pengabdian}

Hal-hal yang melandasi pengabdian ini adalah sebagai berikut:

a. Berdasarkan data Dapodikdasmen, 2018 jumlah guru SD di Dayeuhkolot sangat banyak yaitu sekitar 7.000 guru, akan tetapi masih minim guru yang memanfaatkan barang bekas DAS Citarum dalam pembelajaran RME berupa bahan ajar dan penelitian guru.

b. Seperti halnya persoalan yang sekarang ini sedang menjadi perhatian dunia yaitu Sungai Citarum mendapat peringkat ke-3 sungai terkotor sedunia di akhir tahun 2017 dan Tim Survei Kodam III Siliwangi mencatat sebanyak 20.462 ton sampah organik dan anorganik dibuang ke Sungai Citarum. 
c. Sekolah di Dayeuh Kolot sebagian besar merupakan sekolah yang berada di aliran DAS Citarum oleh karena itu sudah seharusnya warga yang berada di D AS Citarum turut menjaga dan membenahi Citarum dan pada hal ini dapat dilakukan oleh guru dan siswa SD melalui pembelajaran di kelasnya dengan pemanfaatan barang bekas.

d. IKIP Siliwangi adalah kampus yang berada di DAS Citarum dan sudah beberapa tahun kebelakang aktif pada kegiatan membenahi dan melestarikan kawasan sungai citarum khususnya wilayah tengah. Oleh karena itu, para akademisi yaitu dosen dan mahasiswanya mempunyai kewajiban melaksankan pembenahan dan pelestarian melalui pendampingan bagi guru-guru SD di kawasan DAS Citarum.

\section{B. LANDASAN TEORI}

\section{Pendampingan}

Pendampingan merupakan kegiatan pemberian arahan atau bimbingan pada peserta didik dengan tujuan meningkatkan kemampuan atau kompetensi peserta pelatihan. Kamil (2010) mengemukakan bahwa pendampingan adalah suatu kegiatan yang dilakukan seseorang yang bersifat konsultatif, interaktif, komunikatif, motivatif, dan negosiatif. Pemberian pendampingan kepada peserta pelatihan akan memberikan kemudahan untuk pemahaman materi yang sulit dipahami serta memberikan pendampingan yang lebih terstruktur. Dalam kegiatan pelatihan berbasis pendampingan terjadi interaksi dinamis antara peserta pelatihan dengan instruktur pendamping untuk secara bersama-sama menghadapi beragam tantangan(Rahayu GDS dan Firmansyah D, 2018)

\section{Bahan Ajar}

Bahan ajar merupakan salah satu bagian dari sumber ajar yang dapat diartikan sesuatu yang mengandung pesan pembelajaran, baik yang bersifat khusus maupun bersifat umum yang dapat dimanfaatkan untuk kepentingan belajar (Mulyasa, 2006) dan (Rahayu GDS dan Setiyadi R, 2018). Bahan ajar yang dihasilkan diharapkan dapat menjadi referensi para guru Sekolah Dasar dalam mengembangkan pembelajaran matematika dengan model RME berbasis barang-barang bekas.

\section{Pendekatan Realistic Mathematics Education}

Zulkarnain (Murni, 2017) mengatakan bahwa RME juga menekankan untuk membawa matematika pada pengajaran bermakna dengan mengkaitkannya dalam 
kehidupan nyata sehari-hari yang bersifat realistik. Siswa disajikan masalah-masalah kontekstual, yaitu masalah-masalah yang berkaitan dengan situasi realistik. Kata realistik disini dimaksudkan sebagai suatu situasi yang dapat dibayangkan oleh siswa atau menggambarkan situasi dalam dunia nyata.

Menurut Treffers dan Gravemeijer (Chotimah, 2014:18), RME memiliki karakteristik langkah-langkah,

a. Penggunaan Konteks

Proses pembelajaran diawali dengan keterlibatan siswa dalam pemecahan masalah kontekstual.

b. Instrumen Vertikal

Konsep atau ide matematika direkonstruksi oleh siswa melalui model- model instrumen vertikal, yang bergerak dari prosedur informal ke bentuk formal.

c. Kontribusi Siswa

Siswa aktif mengkonstruksi sendiri bahan matematika berdasarkan fasilitas dan lingkungan belajar yang disediakan guru, serta aktif menyelesaikan soal dengan cara masing-masing.

d. Kegiatan Interaktif

Kegiatan belajar bersifat interaktif, yang memungkinkan terjadi komunikasi dan negosiasi antar siswa.

e. Keterkaitan Topik

Pembelajaran suatu bahan matematika terkait dengan berbagai topik matematika secara terintegrasi.

\section{METODE PELAKSANAAN}

Pelaksanaan program pengabdian kepada masyarakat ini dilaksanakan selama 1 minggu di bulan agustus mulai dari tanggal 5-10 Agustus 2019 di Kabupaten Bandung. Metode pelaksanaan pengabdian ini menggunakan metode pendampingan dengan tahap- tahap yaitu: (1) tahap perencanaan, (2) tahap pelaksanaan, (3) tahap evaluasi. Tahap perencanaan telah ditetapkan hal-hal sebagai berikut: tempat/lokasi kegiatan dipilih di kabupaten Bandung barat. Jenis kegiatan berupa pendampingan dalam penyusunan bahan ajar bagi guru-guru SD dengan tema "Penerapan Pembelajaran Realistic Mathematic Education Menggunakan Barang Bekas" 


\section{HASIL DAN PEMBAHASAN}

Hasil

Pengabdian pada masyarakat dilaksanakan di lingkungan UPTD Kecamatan Dayeuhkolot kepada guru-guru Sekolah Dasar mengenai penyusunan bahan ajar dengan tema "penerapan pembelajaran realistic mathematic education menggunakan barang bekas”. Program pengabdian ini dilaksanakan selama 1 minggu dari tanggal 5-10 Agustur 2019 dengan peserta sebanyak 50 peserta.

Langkah pertama program pengabdian ini adalah sosialisasi dan perijinan. Sosialisasi dan perijinan merupakan tahap awal kegiatan. Kegiatan ini bertujuan untuk menginformasikan kepada guru-guru SD mengenai sasaran dan rencana kegiatan pengabdian. Kegiatan ini dilakukan dengan metode diskusi langsung dengan pejabat yang berwenang di bidang pendidikan di wilayah yang menjadi lokasi pengabdian.

Langkah selanjutnya Persiapan pendampingan yaitu mempersiapkan bahan-bahan materi penyusunan bahan ajar dan karya tulis ilmiah dengan tema "Penerapan Pembelajaran Realistic Mathematic Education Menggunakan Barang Bekas". Kami mempersiapkan materi, alat-alat dan perlengkapan lainya untuk kelancaran acara pengabdian tersebut.

Pendampingan dilaksanakaan di luar jam sekolah dan dipusatkan di satu lokasi yang strategis sehingga mudah dijangkau oleh guru-guru SD. Materi yang disampaikan dalam kegiatan ini mencakup penyampaian materi mengenai penyusunan bahan ajar dengan tema "Penerapan Pembelajaran Realistic Mathematic Education Menggunakan Barang Bekas".

Evaluasi yang dilakukan dalam kegiatan ini dilaksankan dengan tidak terlalu formal namun tetap dilaksanakan evaluasi terkait pemahaman guru-guru dalam menyusun bahan ajar dan karya tulis ilmiah dengan tema "Penerapan Pembelajaran Realistic Mathematic Education Menggunakan Barang Bekas". Evaluasi menggunakan format wawancara, kuisioner dan dokumentasi.

Hasil dari pengabdian ini adalah menambah pengalaman para guru-guru mengenai penerapan pembelajaran Realistic Mathematic Education menggunakan barang bekas khususnya dalam pembelajaran matematika di sekolah dasar. Para guru terlihat antusias dengan acara pengabdian ini. Semua pembelajaran matematika yang disajikan di acara pengabdian ini dapat dijadika referensi untuk pembelajaran di sekolah dasar. 


\section{Pembahasan}

Pada kegiatan program pengabdian ini dapat dilihat guru-guru merasa antusias dan aktif. Guru-guru yang menjadi peserta pengabdian merasa mendapatkan ilmu baru terkait pembelajarana matematika dengan model Realistic Mathematics Education menggunakan barang-barang bekas. Pemilihan lokasi pengabdian juga disesuaikan dengan acara pengabdian ini. Lokasi pengabdian yang berada di bantaran sungai citarum yang kondisinya banyak sampah yang dibuang ke sungai.

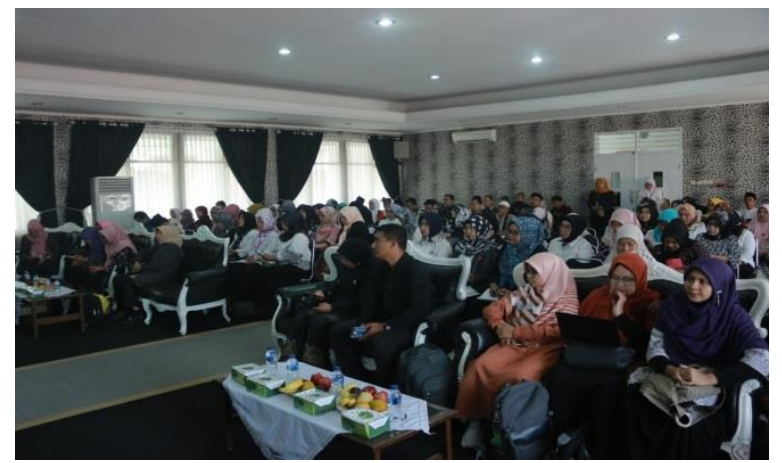

\section{Gambar. 2 guru-guru terlihat antusias dalam acara pangabdian}

Masalah sampah di lokasi pengabdian memang sudah menjadi permasalah yang klasik. Barang bekas yang dipandang tidak berguna dan dipandang kotor dapat dimanfaatkan menjadi barang yang lebih berguna. Oleh karena itu kami memberikan pendampingan kepada guru-guru di daerah tersebut bahwa barang-barang berkas yang tadinya hanya menajdi sampah dapat digunakan menjadi media pembelajaran matematika di sekolah dasar.

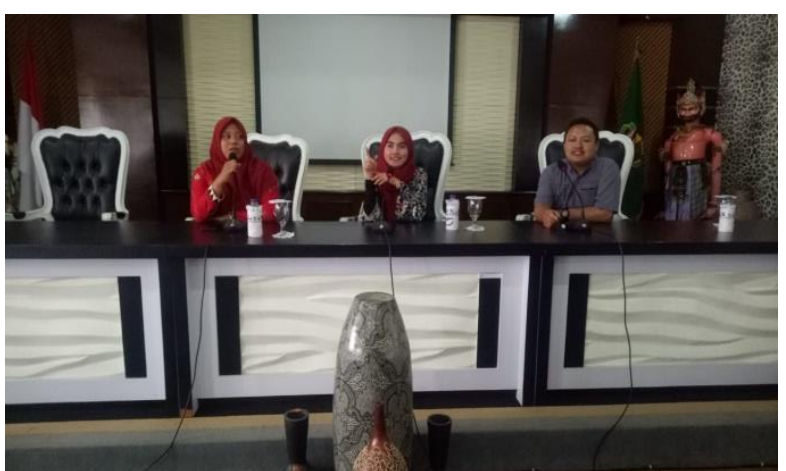

\section{Gambar 2. Pelaksanaan pengabdian pada masyarakat}

Dalam pelaksanaan program pengabdian ini terdapat hambatan-hambatan yang terjadi, antara lain lokasi pengabdian yang baerada di pinggir kota, kendala sarana dan prasarana menjadi hambatan. Selain itu pelaksanaan kegiatan ini setelah pembelajaran di sekolah selesai, jadi peserta pengabdian terlihat lelah dan kurang bersemangat. Pemahaman guru-guru mengeai RME juga sangat minim, mereka terbiasa memberikan pembelajaran matematika kepada siswanya dengan model pembelajaran yang 
konvensional. Pembelajaran matematika hanya menitik berakan pada hapalan bukan pada pemahaman konsep.

\section{E. KESIMPULAN}

Berdasarkan hasil pelaksanaan pengabdian pada masyarakat yang telah dilaksanakan di Kecamtan Dayeuhkolot Kabupaten Bandung, maka dapat disimpulkan hal-hal sebagai berikut:

1. Guru-guru Sekolah Dasar di lingkungan UPTD Dayeuhkolot yang menjadi peserta dalam kegiatan pengabdian ini merasa sangat antusias karena mereka mendapatkan ilmu baru mengenai pembelajaran matematika menggunakan model Realistic Mathematic Education.

2. Kegiatan pengabdian ini dapat dijadika ajang untuk menambah pengatahuan, pemahaman dan pengalaman guru-guru SD pembelajaran matematika dengan menggunakan media dari barang-barang bekas.

3. Wahana atau laboratorium bagi para dosen dalam mengimplementasikan teori, pengetahuan, dan keterampilan secara nyata, dan bermanfaat bagi masyarakat luas.

\section{F. DAFTAR PUSTAKA}

Chotimah, S. (2014). Upaya Meningkatkan Kemampuan Pemahaman dan Komunikasi serta Self Confidence Matematik Siswa SMA Kota Bandung dengan Pendekatan Realistic Mathematics Education. Tesis STKIP Siliwangi. Cimahi: Tidak diterbitkan.

Mulyasa. (2006). Kurikulum tingkat satuan pendidikan. Bandung: Rosdakarya.

Murni, S. (2017). Meningkatkan Kemampuan Berpikir Kritis dan Kreatif serta Resiliansi Matematik Siswa SMA Negeri di Kota Cimahi melalui Pendekatan Realistic Mathematics Education. Tesis. STKIP Siliwangi: Tidak diterbitkan.

Rahayu GDS dan Setiyadi R. (2018). Effect of teaching material Bikin Dongeng Yuk! learning outcomes of class V primary school. PrimaryEdu, 109-116.

Rahayu dan Firmansyah. (2018). Pengembangan pembelajaran inovatif berbasis pendampingan bagi guru sekolah dasar. Abdimas Siliwangi, 17-25.

Sucipto, C. D. S. 2012. Teknologi Pengolahan Daur Ulang Sampah, Yogyakarta: Gosyen publising. 